\title{
Relationship between multidrug resistance 1 polymorphisms and the risk of prostate cancer in Chinese populations
}

\author{
F.R. Shen ${ }^{1,2}$, C.Y. Yan ${ }^{1}$, M. Liu ${ }^{2}$, Y.H. Feng' ${ }^{2}$ and Y.G. Chen ${ }^{3}$ \\ ${ }^{1}$ Department of Urology, First Affiliated Hospital of Soochow University, \\ Suzhou, Jiangsu, China \\ ${ }^{2}$ Department of Obstetrics and Gynecology, Suzhou Kowloon Hospital, \\ Suzhou, Jiangsu, China \\ ${ }^{3}$ Department of Obstetrics and Gynecology, \\ First Affiliated Hospital of Soochow University, Suzhou, \\ Jiangsu, China \\ Corresponding author: Y.G. Chen \\ E-mail: youguochen@sina.cn
}

Genet. Mol. Res. 12 (3): 3806-3812 (2013)

Received January 27, 2013

Accepted August 23, 2013

Published September 19, 2013

DOI http://dx.doi.org/10.4238/2013.September.19.12

\begin{abstract}
Prostate cancer is one of the most common malignancies in men. The multidrug resistance 1 gene $(M D R 1)$ is an important candidate gene for prostate cancer. The aim of this study was to evaluate the association between MDR 1 gene polymorphisms and the risk of prostate cancer. $M D R 1$ gene polymorphism and its association with the risk of prostate cancer were investigated in 357 Chinese men. A novel c. $1465 \mathrm{C}>\mathrm{T}$ polymorphism was detected with created restriction site-polymerase chain reaction and DNA sequencing. We found a significantly increased risk of prostate cancer in the homozygote comparison [TT vs CC: odds ratio $(\mathrm{OR})=2.300$, $95 \%$ confidence interval $(95 \% \mathrm{CI})=1.261-4.196$, chi-square $=7.53$, $\mathrm{P}=0.007$, heterozygote comparison ( $\mathrm{TC}$ vs $\mathrm{CC}: \mathrm{OR}=1.667,95 \% \mathrm{CI}$ $=1.049-2.648$, chi-square $=4.71, \mathrm{P}=0.030)$, dominant model $(\mathrm{TT} /$
\end{abstract}


TC $v_{s} \mathrm{CC}: \mathrm{OR}=1.835,95 \% \mathrm{CI}=1.197-2.815$, chi-square $=7.81, \mathrm{P}=$ $0.005)$, recessive model (TT vs TC/CC: $\mathrm{OR}=1.776,95 \% \mathrm{CI}=1.023$ 3.085, chi-square $=4.23, \mathrm{P}=0.041)$, and allele contrast $(\mathrm{T}$ vs $\mathrm{C}: \mathrm{OR}$ $=1.625,95 \% \mathrm{CI}=1.199-2.202$, chi-square $=9.87, \mathrm{P}=0.002)$. These findings suggested that the c. $1465 \mathrm{C}>\mathrm{T}$ polymorphism of $M D R 1$ may be risk factors for prostate cancer in Chinese men.

Key words: Association analysis; Prostate cancer; Risk factors; Multidrug resistance 1 gene; Single-nucleotide polymorphism;

\section{INTRODUCTION}

Prostate cancer (Pca) is among the most common malignancies in men and the second leading cause of cancer-related death (Jemal et al., 2008). The pathogenesis of Pca is still largely unknown, with genetic and environmental factors likely contributing to increased risk of the disease (Pienta and Esper 1993; Lichtenstein et al., 2000; Schaid, 2004). Several candidate genes have been suggested to be associated with Pca, including multidrug resistance 1 (MDR1) (van Brussel and Mickisch, 2003; Sanchez et al., 2009; Sanchez et al., 2011), X-ray repair complementing group 1 (Hirata et al., 2007; Agalliu et al., 2010; Dhillon et al., 2011; Kuasne et al., 2011; Langsenlehner et al., 2011), xeroderma pigmentosum group D gene (Mandal et al., 2010), APEX nuclease 1 gene (Agalliu et al., 2010; Kuasne et al., 2011; Mittal et al., 2012), Toll-like receptor 4 (Jing et al., 2012), axis inhibition protein 2 (Pinarbasi et al., 2011), 2-5A-dependent RNase (Wei et al., 2012), complementation group $\mathrm{G}$ gene (Berhane et al., 2012), and $\mathrm{N}$-acetyltransferase types 1 (Gong et al., 2011) and 2 (Gong et al., 2011; de Lima Junior et al., 2012). MDR1 is an important candidate gene for Pca. Evidence from previous studies has suggested that common polymorphisms in MDRI are associated with the risk of Pca (van Brussel and Mickisch, 2003; Sanchez et al., 2009; Sanchez et al., 2011). Several MDR1 singlenucleotide polymorphisms (SNPs) such as C2677T and C3435T have been detected to affect the risk of Pca (Narter et al., 2006). However, no similar association analysis has been carried out for the c. $1465 \mathrm{C}>\mathrm{T}$ variant in $M D R 1$ and risk of Pca. The current study aimed to investigate the $M D R 1 \mathrm{c} .1465 \mathrm{C}>\mathrm{T}$ variant distribution and evaluate its effect on the risk of Pca in Chinese men.

\section{MATERIAL AND METHODS}

\section{Subjects}

A total of 176 Pca patients and 181 healthy controls were recruited for this study. The subject characteristics are summarized in Table 1 and included age, drinking status, smoking status, body mass index, family history of Pca, serum prostate-specific antigen level (ng/mL), and Gleason grade. All subjects were genetically unrelated ethnic Han Chinese men. The diagnosis of Pca was confirmed with pathological, clinical, and laboratory examinations. This study was approved by the local ethics committee, and written informed consent forms were obtained from all subjects. 


\begin{tabular}{|c|c|c|c|c|c|c|}
\hline \multirow[t]{2}{*}{ Characteristics } & \multicolumn{2}{|c|}{ Cases $(\mathrm{N})$} & \multicolumn{2}{|c|}{ Controls $(\mathrm{N})$} & \multirow[t]{2}{*}{$\chi^{2}$-value } & \multirow[t]{2}{*}{$\mathrm{P}$} \\
\hline & 176 & $\%$ & 181 & $\%$ & & \\
\hline Age years, means \pm SD & $72.83 \pm 9.79$ & & $71.76 \pm 9.58$ & & 2.2391 & 0.1346 \\
\hline$\geq 75$ & 110 & 62.50 & 99 & 54.70 & & \\
\hline$<75$ & 66 & 37.50 & 82 & 45.30 & & \\
\hline Drinking & & & & & 0.7425 & 0.3888 \\
\hline Yes & 61 & 34.66 & 55 & 30.39 & & \\
\hline No & 115 & 65.34 & 126 & 69.61 & & \\
\hline Smoking & & & & & 1.6020 & 0.2056 \\
\hline Yes & 106 & 60.23 & 97 & 53.59 & & \\
\hline No & 70 & 39.77 & 84 & 46.41 & & \\
\hline Body mass index (BMI) $\left(\mathrm{kg} / \mathrm{m}^{2}\right)$ & & & & & 0.5043 & 0.4776 \\
\hline$\geq 25$ & 98 & 55.68 & 94 & 51.93 & & \\
\hline$<25$ & 78 & 44.32 & 87 & 48.07 & & \\
\hline \multicolumn{7}{|l|}{ Family history of prostate cancer } \\
\hline Yes & 42 & 23.86 & - & & & \\
\hline No & 134 & 76.14 & - & & & \\
\hline \multicolumn{7}{|l|}{ Serum PSA level $(\mathrm{ng} / \mathrm{mL})$} \\
\hline$\geq 10$ & 128 & 72.73 & - & & & \\
\hline$<10$ & 48 & 27.27 & - & & & \\
\hline \multicolumn{7}{|l|}{ Gleason score } \\
\hline$\geq 7$ & 116 & 65.91 & - & & & \\
\hline$<7$ & 60 & 34.09 & - & & & \\
\hline
\end{tabular}

\section{Genotype analysis}

Blood samples were collected from all subjects, and genomic DNA was extracted according to a standard protocol. Specific polymerase chain reaction (PCR) primers were designed using Primer Premier 5.0 software (Premier Biosoft International, Palo Alto, CA). Primers, annealing temperature, region, fragment size, and selected restriction enzymes (MBI Fermentas, St. Leon-Rot, Germany) are presented in Table 2. PCR amplifications were performed with $20-\mu \mathrm{L}$ reaction mixtures containing $50 \mathrm{ng}$ mixed DNA template, $10 \mathrm{pM}$ each primer, $0.20 \mathrm{mM}$ deoxyribonucleotide triphosphate, $2.5 \mathrm{mM} \mathrm{MgCl}_{2}$, and $0.5 \mathrm{U}$ Taq DNA polymerase (TaKaRa, Dalian, China). The PCR protocol was $95^{\circ} \mathrm{C}$ for 5 min followed by 32 cycles of $94^{\circ} \mathrm{C}$ for $30 \mathrm{~s}, 59.2^{\circ} \mathrm{C}$ for $30 \mathrm{~s}$, and $72^{\circ} \mathrm{C}$ for $30 \mathrm{~s}$, and a final extension at $72^{\circ} \mathrm{C}$ for $10 \mathrm{~min}$. The c. 1465C $>$ T variant was detected with a created restriction site-PCR (CRS-PCR) method with 1 of the primers containing a nucleotide mismatch, which enabled the use of restriction enzymes for discriminating sequence variations (Haliassos et al., 1989; Zhao et al., 2003; Yuan et al., 2012; Yuan et al., 2013; Yuan et al., 2013). Following the supplier manual, we digested $5-\mu \mathrm{L}$ aliquots PCR amplified products with $2 \mathrm{U}$ restriction enzyme at $37^{\circ} \mathrm{C}$ for $10 \mathrm{~h}$. The digested products were separated via electrophoresis in $2.5 \%$ agarose gel, and the genotype of the c.1465C $>\mathrm{T}$ polymorphism was based on the various electrophoretic patterns. The PCR-amplified products were sent to the Bioasia Biotechnology Co., Ltd. (Shanghai, China) for sequencing on an ABI 3730 sequencer (Applied Biosystems, Foster City, CA 94404, USA) to verify the findings of the CRS-PCR analysis.

\section{Statistical analysis}

The chi-square test was used to evaluate Hardy-Weinberg equilibrium and compare 
the genotype frequencies between patients and controls. The odds ratio (OR) and 95\% confidence intervals $(95 \% \mathrm{CI})$ were obtained through multiple and logistic regression analyses to investigate the association between the MDRl polymorphism and susceptibility to Pca. All statistical analyses were performed using SPSS (Windows version release 15.0; SPSS Inc.; Chicago, IL, USA). A P value of less than 0.05 was regarded as statistically significant.

Table 2. Primer and CRS-PCR analysis for detecting the c. $1465 \mathrm{C}>\mathrm{T}$ polymorphism in MDR1 gene.

\begin{tabular}{lccccc}
\hline Primer sequences & $\begin{array}{c}\text { Annealing } \\
\text { temperature }\left({ }^{\circ} \mathrm{C}\right)\end{array}$ & $\begin{array}{c}\text { Amplification } \\
\text { fragment }(\mathrm{bp})\end{array}$ & Region & $\begin{array}{c}\text { Restriction } \\
\text { enzyme }\end{array}$ & Genotype (bp) \\
\hline 5'-CACCACGATAGCTGAAAACATC-3' & 59.2 & 220 & Exon14 & Aci & $\begin{array}{l}\text { CC: } 198,22 \\
\text { CT: } 220,198,22 \\
\text { 5'-TTAGGATTTCCCTTCTTCCGAT-3' }\end{array}$ \\
\hline
\end{tabular}

CRS-PCR $=$ polymerase chain reaction-created restriction site-polymerase chain reaction; underlined nucleotides mark nucleotide mismatches enabling the use of the selected restriction enzymes for detecting sequence polymorphism.

\section{RESULTS}

\section{General characteristics of the subjects}

In total, 357 subjects were evaluated in this study and their characteristics are presented in Table 1. No significant differences were found between Pca patients and healthy controls in terms of age, drinking, smoking, and body mass index $(\mathrm{P}=0.1346, \mathrm{P}=0.3888, \mathrm{P}$ $=0.2056$, and $\mathrm{P}=0.4776$, respectively).

\section{Genotyping of MDR1 polymorphism}

We founded the c.1465C $>\mathrm{T}$ variant within exon14 of the human MDR1 gene using CRS-PCR and DNA sequencing methods. Sequence analysis showed that the c.1465C $>\mathrm{T}$ polymorphism was caused by a $\mathrm{C}$ to $\mathrm{T}$ mutation, resulting in arginine (Arg) to cysteine (Cys) amino acid replacement (p.Arg489Cys; reference sequences GenBank IDs NG_011513.1, NM_000927.4, and NP_000918.2). The PCR product of the c.1465C $>\mathrm{T}$ variant was digested with AciI enzyme and divided into 3 genotypes: CC (198 and 22 bp), CT (220, 198, and 22 bp), and TT (220 bp; see Table 2). The allelic and genotypic frequencies of the c. $1465 \mathrm{C}>\mathrm{T}$ polymorphisms appear in Table 3 . The chi-square test suggested that the $\mathrm{c} .1465 \mathrm{C}>\mathrm{T}$ polymorphism was in Hardy-Weinberg equilibrium in the cases and controls $(\mathrm{P}>0.05)$. Allele frequencies were 0.5568 and 0.6713 for the $\mathrm{C}$ allele, and 0.4432 and 0.3287 for the $\mathrm{T}$ allele in Pca patients and healthy controls, respectively. Frequencies of the CC, CT, and TT genotypes were $0.3352,0.4432$, and 0.2216 in cases, whereas the frequencies of those genotypes in controls were $0.4807,0.3812$, and 0.1381 . The allelic and genotypic frequencies of patients were significantly different from those of controls (chi-square $=9.8720, \mathrm{P}=0.0017$, and chi-square $=8.9151, \mathrm{P}=0.0116$, respectively; see Table 3 ).

\section{Association analysis of $M D R 1$ polymorphism with risk of Pca}

Table 4 shows the association between the c. $1465 \mathrm{C}>\mathrm{T}$ polymorphism and the risk of 
Pca. Significantly increased risk of Pca occurred in the homozygote comparison (TT vs CC: $\mathrm{OR}=2.300,95 \% \mathrm{CI}=1.261-4.196$, chi-square $=7.53, \mathrm{P}=0.007$ ), heterozygote comparison ( $\mathrm{TC}$ vs $\mathrm{CC}: \mathrm{OR}=1.667,95 \% \mathrm{CI}=1.049-2.648$, chi-square $=4.71, \mathrm{P}=0.030)$, dominant model (TT/TC vs CC: $\mathrm{OR}=1.835,95 \% \mathrm{CI}=1.197-2.815$, chi-square $=7.81, \mathrm{P}=0.005)$, recessive model $(\mathrm{TT} v s \mathrm{TC} / \mathrm{CC}: \mathrm{OR}=1.776,95 \% \mathrm{CI}=1.023-3.085$, chi-square $=4.23, \mathrm{P}=0.041)$, and allele contrast ( $\mathrm{T} v \mathrm{C}: \mathrm{OR}=1.625,95 \% \mathrm{CI}=1.199-2.202$, chi-square $=9.87, \mathrm{P}=0.002$ ).

\begin{tabular}{|c|c|c|c|c|c|c|c|}
\hline & \multicolumn{3}{|c|}{ Genotypes } & \multicolumn{2}{|c|}{ Alleles } & \multirow[t]{2}{*}{$\chi^{2}$} & \multirow[t]{2}{*}{$P$} \\
\hline & $\mathrm{CC}$ & CT & TT & $\mathrm{C}$ & $\mathrm{T}$ & & \\
\hline Case Group (N=176) & $59(0.3352)$ & $78(0.4432)$ & $39(0.2216)$ & $196(0.5568)$ & $156(0.4432)$ & 1.8326 & 0.4000 \\
\hline Control Group $(\mathrm{N}=181)$ & $87(0.4807)$ & $69(0.3812)$ & $25(0.1381)$ & $243(0.6713)$ & $119(0.3287)$ & 3.3585 & 0.1865 \\
\hline Total $(\mathrm{N}=357)$ & $146(0.4090)$ & $\begin{array}{c}147(0.4117) \\
\chi^{2}=8.9151, \mathrm{P}=0.0116\end{array}$ & $64(0.1793)$ & $\begin{array}{r}439(0.6148) \\
\quad \chi^{2}=9.872\end{array}$ & $\begin{array}{l}275(0.3852) \\
P=0.0017\end{array}$ & 6.0894 & 0.0476 \\
\hline
\end{tabular}

Table 4. Association between the susceptibility of prostate cancer and the c. $1465 \mathrm{C}>\mathrm{T}$ variant in $M D R 1$ gene.

\begin{tabular}{lccr}
\hline Comparisons & \multicolumn{3}{c}{ Test of association } \\
\cline { 2 - 4 } & OR $(95 \% \mathrm{CI})$ & $\chi^{2}$ & $\mathrm{P}$ \\
\hline TT $v s$ CC (homozygote comparison) & $2.300(1.261-4.196)$ & 4.53 & 0.007 \\
TC $v s$ CC (heterozygote comparison) & $1.667(1.049-2.648)$ & 7.81 & 0.030 \\
TT/TC $v$ CC (dominant model) & $1.835(1.197-2.815)$ & 4.23 & 0.005 \\
TT $v$ TC/CC (recessive model) & $1.776(1.023-3.085)$ & 9.87 & 0.041 \\
T $v s$ C (allele contrast) & $1.625(1.199-2.202)$ & 0.002
\end{tabular}

$\mathrm{OR}=$ odds ratio $; 95 \% \mathrm{CI}=95 \%$ confidence interval.

\section{DISCUSSION}

Pca is a multi-factorial disease resulting from complex factors, and genetic factors play an important role in the risk of Pca. Previous studies have demonstrated that MDR1 is an important candidate gene in the pathogenesis of osteoporosis (van Brussel and Mickisch, 2003; Sanchez et al., 2009; Sanchez et al., 2011). To the best of our knowledge, the current study is the first to investigate the prevalence of the c. $1465 \mathrm{C}>\mathrm{T}$ variant, which is located in exon14 of MDR1, and evaluate its relationship with Pca risk. Our data showed that the MDR1 c. $1465 \mathrm{C}>\mathrm{T}$ variant is associated with the risk of Pca in Chinese men. The genotypic and allelic frequencies between patients and healthy controls were statistically associated with this risk $(\mathrm{P}=0.0116$ and $\mathrm{P}=0.0017$, respectively; see Table 3$)$. The TT genotype was strongly associated with increased risk of Pca compared to that accompanying the CC genotype and CT/ $\mathrm{CC}$ carrier status $(\mathrm{OR}=2.300,95 \% \mathrm{CI}=1.261-4.196, \mathrm{P}=0.007$, and $\mathrm{OR}=1.776,95 \% \mathrm{CI}=$ 1.023-3.085, $\mathrm{P}=0.041$; see Table 4). In addition, the $\mathrm{T}$ allele increased the risk of Pca ( $\mathrm{T}$ vs $\mathrm{C}$ : $\mathrm{OR}=1.625,95 \% \mathrm{CI}=1.199-2.202, \mathrm{P}=0.002$; see Table 4). Similar research has reported that several MDR1 SNPs, such as C2677T and C3435T (Narter et al., 2006), are associated with the risk of Pca, but the c.1465C $>\mathrm{T}$ variant was not included in that study. Results from this study provide more evidence for the role of MDR1 in Pca. However, the mechanism underly- 
ing the association between the MDR1 SNPs and the risk of Pca is still poorly understood. Thus, further studies are necessary to obtain more reliable results in larger populations and to augment the etiology in the pathogenesis of Pca.

\section{Conflicts of interest}

The authors declare no conflicts of interests.

\section{REFERENCES}

Agalliu I, Kwon EM, Salinas CA, Koopmeiners JS, et al. (2010). Genetic variation in DNA repair genes and prostate cancer risk: results from a population-based study. Canc. Causes Contr. 21: 289-300.

Berhane N, Sobti RC and Mahdi SA (2012). DNA repair genes polymorphism (XPG and XRCC1) and association of prostate cancer in a north Indian population. Mol. Biol. Rep. 39: 2471-2479.

de Lima Junior MM, Reis LO, Guilhen AC, Granja F, et al. (2012). N-acetyltransferase-2 gene polymorphisms and prostate cancer susceptibility in Latin American patients. Med. Oncol. 29: 2889-2894.

Dhillon VS, Yeoh E and Fenech M (2011). DNA repair gene polymorphisms and prostate cancer risk in South Australia results of a pilot study. Urol. Oncol. 29: 641-646.

Gong C, Hu X, Gao Y, Cao Y, et al. (2011). A meta-analysis of the NAT1 and NAT2 polymorphisms and prostate cancer: a huge review. Med. Oncol. 28: 365-376.

Haliassos A, Chomel JC, Tesson L, Baudis M, et al. (1989). Modification of enzymatically amplified DNA for the detection of point mutations. Nucleic Acids Res. 17: 3606.

Hirata H, Hinoda Y, Tanaka Y, Okayama N, et al. (2007). Polymorphisms of DNA repair genes are risk factors for prostate cancer. Eur. J. Canc. 43: 231-237.

Jemal A, Siegel R, Ward E, Hao Y, et al. (2008). Cancer statistics, 2008. CA Canc. J. Clin. 58: 71-96.

Jing JJ, Li M and Yuan Y (2012). Toll-like receptor 4 Asp299Gly and Thr399Ile polymorphisms in cancer: a metaanalysis. Gene 499: 237-242.

Kuasne H, Rodrigues IS, Losi-Guembarovski R, Reis MB, et al. (2011). Base excision repair genes XRCC1 and APEX1 and the risk for prostate cancer. Mol. Biol. Rep. 38: 1585-1591.

Langsenlehner T, Renner W, Gerger A, Hofmann G, et al. (2011). Association between single nucleotide polymorphisms in the gene for XRCC1 and radiation-induced late toxicity in prostate cancer patients. Radiother. Oncol. 98: 387-393.

Lichtenstein P, Holm NV, Verkasalo PK, Iliadou A, et al. (2000). Environmental and heritable factors in the causation of cancer-analyses of cohorts of twins from Sweden, Denmark, and Finland. N. Engl. J. Med. 343: 78-85.

Mandal RK, Gangwar R, Mandhani A and Mittal RD (2010). DNA repair gene X-ray repair cross-complementing group 1 and xeroderma pigmentosum group D polymorphisms and risk of prostate cancer: a study from North India. DNA Cell Biol. 29: 183-190.

Mittal RD, Mandal RK and Gangwar R (2012). Base excision repair pathway genes polymorphism in prostate and bladder cancer risk in North Indian population. Mech. Ageing Dev. 133: 127-132.

Narter F, Yilmaz H, Yücebas E, Sengör F, et al. (2006). Effects of MDR1 C3435T wobble polymorphism on metastase and tumor stage in prostate cancer. Adv. Mol. Med. 2: 23-28.

Pienta KJ and Esper PS (1993). Risk factors for prostate cancer. Ann. Intern. Med. 118: 793-803.

Pinarbasi E, Gunes EG, Pinarbasi H, Donmez G, et al. (2011). AXIN2 polymorphism and its association with prostate cancer in a Turkish population. Med. Oncol. 28: 1373-1378.

Sanchez C, Mendoza P, Contreras HR, Vergara J, et al. (2009). Expression of multidrug resistance proteins in prostate cancer is related with cell sensitivity to chemotherapeutic drugs. Prostate 69: 1448-1459.

Sanchez C, Mercado A, Contreras HR, Mendoza P, et al. (2011). Chemotherapy sensitivity recovery of prostate cancer cells by functional inhibition and knock down of multidrug resistance proteins. Prostate 71: 1810-1817.

Schaid DJ (2004). The complex genetic epidemiology of prostate cancer. Hum. Mol. Genet. 13 Spec No 1: R103-R121.

van Brussel JP and Mickisch GH (2003). Multidrug resistance in prostate cancer. Onkologie 26: 175-181.

Wei B, Xu Z, Ruan J, Zhu M, et al. (2012). RNASEL Asp541Glu and Arg462Gln polymorphisms in prostate cancer risk: evidences from a meta-analysis. Mol. Biol. Rep. 39: 2347-2353.

Yuan Z, Li J, Li J, Zhang L, et al. (2012). Investigation on BRCA1 SNPs and its effects on mastitis in Chinese commercial cattle. Gene 505: 190-194. 
Yuan Z, Li J, Li J, Gao X, et al. (2013). SNPs identification and its correlation analysis with milk somatic cell score in bovine MBL1 gene. Mol. Biol. Rep. 40: 7-12.

Yuan Z, Li J, Li J, Gao X, et al. (2013). Effects of DGAT1 gene on meat and carcass fatness quality in Chinese commercial cattle. Mol. Biol. Rep. 40: 1947-1954.

Zhao CJ, Li N and Deng XM (2003). The establishment of method for identifying SNP genotype by CRS-PCR. Yi Chuan 25: 327-329. 